\title{
Erratum to: State and Politics in Religious Peacebuilding
}

\author{
Tale Steen-Johnsen
}

\section{Erratum to:}

Tale Steen-Johnsen, State and Politics in Religious Peacebuilding, Palgrave Studies in Compromise after Conflict, DOI 10.1057/978-1-137-59390-0

The series preface of this title was inadvertently missed in the previous version of this book and it has been included in this version.

The updated online version of the original book can be found under DOI $10.1057 / 978-1-137-59390-0$ 